\title{
Identifying capabilities in innovation projects: Evidences from eHealth 27
}

\author{
Alberto Urueña $^{\mathrm{a}, *}$, Antonio Hidalgo ${ }^{\mathrm{a}}$, Álvaro E. Arenas ${ }^{\mathrm{b}}$ \\ " Universidad Polttécnica de Madrid, c/ José Guttérrez Abascal, 2, Madrıld 28006, Spaln \\ b IE Bustness School, c/Marla de Molina, 11, Madrld 28006, Spain
}

\section{A B S T R A C T}

Many eHealth innovation projects have emerged in the last few years, but most of them remain in a permanent pilot state, which is a growing concern in the management literature. The purpose of this study is to improve the understanding of the organizational capabilities that eHealth innovation projects require after the pilot state. The analysis follows an inductive theory building process comprising two qualitative studies. The first study derives propositions relating organizational capabilities to the implementation of eHealth projects from interviews with five experts in the area. Four capabilities emerge from the interviews: evaluation, collaborative leadership, stakeholder networking, and organizational flexibility. A second study validates the propositions analyzing seven eHealth projects that have reached implementation. This research also provides insight for managers of eHealth projects on how to define strategies to take their projects from pilot to real implementations, avoiding the so called "plague of pilots."

Keywords: Organizational capabilities, Innovation projects, eHealth, Inductive theory building

\section{Introduction}

Healthcare systems in the Western world are confronting a significant pressure to reduce costs while improving last decades' quality of health service delivery. Several factors, such as an aging population, increasing mobility of patients, or lack of qualified health works, complicate the fulfillment of this purpose (Hedberg \& Morosi, 2015). In addition, society expects solving today's problems through the extensive use of information and communication technologies (ICT) in healthcare; thus, Eysenbach (2001) introduced the term eHealth, which emerges as a sil ver bullet for achieving cost savings, efficiency, and quality in healthcare (Car, Black, Anandan, Cresswell, \& Pagliari, 2008).

Many eHealth innovation projects have emerged in the last few years, but most of them remain in a permanent pilot state, which is a growing concern among researchers and policymakers. Scholars have identified the need to uncover mechanisms that help in achieving successful eHealth implementation (Andreassen, Kjekshus, \& Tjora, 2015). Previous work identifies capabilities that organizations need to innovate and, more specifically, to co create value and knowledge with other stakeholders in innovation projects (Den Hertog, Van der Aa, \& de Jong, 2010; Kazadi, Lievens, \& Mahr, 2016; Sharma, Conduit, \& Hill, 2014). However, the scientific literature on the required capabil ities to implement innovation projects after the pilot stage is scarce.

म The authors thank José Albors, Universidad Politécnica de Valencia (Spain) and Cali Nuur, Royal Institute of Technology (Sweden), for their careful reading and suggestions.

* Corresponding author.

E-mail addresses: alberto.uruena@upm.es (A. Urueña), antonio.hidalgo@upm.es (A. Hidalgo), alvaro.arenas@ie.edu (Á.E. Arenas).
The purpose of this study is to improve the understanding of the organizational capabilities necessary in innovation projects after the pilot state, focusing on eHealth projects. Organizational capabilities are bundles of skills and accumulated knowledge that enable companies to coordinate activities and use their assets (Day, 1994). These capabil ities allow companies to respond quickly to changing customer prefer ences and creating a competitive advantage. Therefore, understanding the organizational capabilities that a company needs to lead the suc cessful implementation of innovation projects in general, and eHealth projects in particular, is of great theoretical and practical importance.

This study aims to respond to the following research question: How do organizational capabilities contribute to take eHealth innovation projects from a pilot stage to a real implementation?

In answering the above research question, the study examines Kurt Lewin's (1945) contribution to science and follows an inductive theory building process comprising two qualitative studies. The first study derives propositions about organizational capabilities in eHealth from five interviews with eHealth experts. A second study validates the propositions by analyzing seven implemented eHealth projects.

The primary contribution of this study is explaining the organiza tional capabilities required for taking eHealth innovation projects from pilot to the implementation stage. The study also provides relevant insight for managers of eHealth projects and policy makers to define strategies to take their projects from pilot to real implementations, avoiding the so called "plague of pilots" (Andreassen et al., 2015).

The remainder of this research has the following structure. Section 2 describes antecedents of organizational capabilities through a review of the literature and the problem of the plague of pilots in eHealth projects. Section 3 describes the research method and the data collection. 
Section 4 presents the main findings, and Section 5 discusses conclu sions and research limitations.

\section{Literature review}

The resource based view of the firm (RBV) posits that the combina tion of heterogeneous resources with the firm's inner knowledge is a key driver of competitive advantage (Barney, 1991). This combination allows companies to generate knowledge that translates into innova tion, which is difficult to diagnose and to replicate by competitors (Teece, 2014). This approach emphasizes that resources are easily transferable between organizations (Wu, Chen, \& Jiao, 2016); thus, companies need to transform their resources into capabilities that allow them to achieve superior performance by weaving employees' tacit knowledge of the organization, which is more difficult to imitate and transfer (Makadok, 2001).

Companies require organizational, static, and dynamic capabilities to efficiently respond to changes in their environment; these capabilities should be part of the strategic plan of the company (O'Connor, 2008). Developing organizational capacities requires changes in the structures of power (Francis \& Bessant, 2005) and in the activities related to knowledge and learning (Madhavan \& Grover, 1998). Christensen (1997) described the organizational capabilities as a multidimensional construct that includes factors such as human, technologic, and material resources, and processes and criteria for decision making.

For companies, the innovative capability in changing environments is vital (Calantone, Cavusgil, \& Zhao, 2002; Romijn \& Albaladejo, 2002). The capability to innovate is the capability to generate and create new knowledge in the collective creation of value (Le Masson, Weil, \& Hatchuel, 2010), which stems from the organizational capabilities of the firm (Grant, 1996). Previous work identifies organizational capabil ities related to innovation in knowledge co creation (Kazadi et al., 2016), radical innovation (Forés \& Camisón, 2016), value co creation (Galvagno \& Dalli, 2014), and customer value (Martelo, Barroso, \& Cepeda, 2013), among others.

A systematic review of the literature on the implementation of eHealth projects shows that methodological quality in this area is poor and provides little information on the ways in which managers and other users understand of eHealth systems (Mair et al., 2012). The so called "plague of pilots" exacerbates the situation; "plague of pilots" is a term that Wyatt and Sullivan (2005) introduced to refer to the fact that many eHealth projects run as non permanent test projects rather than as normal practice. The literature on the topic points out that eHealth projects seem to meet the criteria for technical success, "yet fail to become part of every day clinical routine" (de Bont \& Bal, 2008, p. 1). In previous work, scholars determine as potential reason for such a problem, among others, the failure of adapting the individual or ganization to new eHealth required management structures (Broens, Vollenbroek Hutten, Hermens, van Halteren, \& Nieuwenhuis, 2007).

Table 1 shows the main organizational capabilities related to innova tion that the literature identifies; the analysis uses them as the starting point to study capabilities in eHealth innovation projects.

\section{Methods}

This study employs an analytic induction method (Patton, 2002) to design a theory through a case study (Gomm, Hammersley, \& Foster, 2000), using data from two qualitative studies. The method is appropri ate to analyze the research questions, allowing integrating various sources of information inductively (Eisenhardt, 1989; Woodside \& Wilson, 2003). The case method has also proved its suitability for pro cess analysis, useful in information systems research (Miles, Huberman, \& Saldana, 2013). Although the results of this method are difficult to generalize, the method allows examining certain proposi tions (Yin, 1994). Drawing from organizational capabilities, the study applies a theory development approach consistent with what Gregor
Table 1

Organizational capabilities related to innovation obtained from the literature review.

\begin{tabular}{|c|c|c|}
\hline Capability & Sources & Sector \\
\hline Absorptive capability & $\begin{array}{l}\text { Forés and Camisón (2016) } \\
\text { Kazadi et al. (2016) }\end{array}$ & $\begin{array}{l}\text { Industrial } \\
\text { Health }\end{array}$ \\
\hline Stakeholder networking & Kazadi et al. (2016) & Health \\
\hline \multicolumn{3}{|l|}{ Stakeholder competence mapping } \\
\hline \multicolumn{3}{|l|}{ Stakeholder relational } \\
\hline \multicolumn{3}{|l|}{ Stakeholder knowledge management } \\
\hline Leadership & Sharma et al. (2014) & Health \\
\hline \multicolumn{3}{|l|}{ Collaborative integration of resources } \\
\hline \multicolumn{3}{|l|}{ Customer mobilization } \\
\hline \multicolumn{3}{|l|}{ Customer identification } \\
\hline \multicolumn{3}{|l|}{ Customer agility } \\
\hline \multicolumn{3}{|l|}{ Responding to customer needs } \\
\hline \multicolumn{3}{|l|}{ Organizational flexibility } \\
\hline \multicolumn{3}{|l|}{ Evaluation } \\
\hline \multicolumn{3}{|l|}{ Interaction capabilities } \\
\hline Market sensing capability & Day (2011) & Marketing \\
\hline \multicolumn{3}{|l|}{ Market learning } \\
\hline \multicolumn{3}{|l|}{ Market experimentation } \\
\hline Market orientation & Martelo et al. (2013) & Marketing \\
\hline \multicolumn{3}{|l|}{ Knowledge management } \\
\hline \multicolumn{3}{|l|}{ Customer relation management } \\
\hline Opportunity-recognizing capability & Wu et al. (2015) & Industrial \\
\hline \multicolumn{3}{|l|}{ Opportunity-capitalizing capability } \\
\hline Internal knowledge creation capability & Forés and Camisón (2016) & Industrial \\
\hline \multicolumn{3}{|l|}{ Radical innovation performance } \\
\hline Incremental innovation performance & & \\
\hline
\end{tabular}

(2006) referred to as "theory for explaining." Using this process oriented narrative (Van de Ven \& Poole, 2005), the study explains how organizational capabilities contribute in transitioning eHealth innovation projects from pilot to real implementation.

\subsection{Data collection and analysis}

The study collects all data in Spain; this country offers an interesting opportunity because of its progress in eHealth, according to internation al records, during the time of a financial crisis. Since the eighties of last century, the Spanish national health system offers virtually universal coverage, including a variety of services through a wide network of hos pitals and health centers, following a decentralized relatively low cost model compared to other European countries (Borkan, Eaton, Novillo Ortiz, Corte, \& Jadad, 2010).

Spain is among the leading countries in Europe in relation to making appointments with doctors through Internet. In 2014, 27.5\% of Spanish citizens have concluded appointments in this way, placing Spain in the third position according to Digital Agenda Scoreboard of the European Commission. In addition, Spain obtained the fourth position across the European Union in the compound of electronic records of information in primary care (Codagnone \& Lupiañez Villanueva, 2013), and the country ranked second in Europe in access to health information using mobile phones (Lupiañez, Maghiros, \& Abadie, 2013).

The first study included interviews with five experts in eHealth from the government and the private sectors, previously involved in the implementation of eHealth innovation projects with different rates of success (Table 2). The interviews are face to face or by phone, with a duration of $60 \mathrm{~min}$ on average. The study uses the recordings and tran scriptions of all interviews. The interviews consist of a semi structured questionnaire that, after a brief introduction to the study, asks about the participants' opinions and knowledge on the "plague of pilots," and about the key capabilities for transitioning eHealth pilots into projects, using as starting point the capabilities appearing in the literature review. The study also obtains additional data from reports from the United Nation, European Commission, and the Spanish Health Informatics Society, among other sources. The analysis applied induc tive theory building to the data from the first stage, which results in 
Table 2

Experts in eHealth interviewed in the first study and their profile.

\begin{tabular}{cll}
\hline Experts & Profile & $\begin{array}{c}\text { Years of } \\
\text { experience }\end{array}$ \\
\hline Expert & $\begin{array}{l}\text { B.Sc. in Political Science and Sociology, Former Regional } \\
\text { Minister of Health, Subdirector for health affairs in a } \\
\text { national public agency }\end{array}$ & 30 \\
Expert & $\begin{array}{l}\text { B.Sc. in Sociology, M.Sc. in Data Analysis, Manager eHealth } \\
\text { research projects, Consultant in eHealth }\end{array}$ & 15 \\
Expert & $\begin{array}{l}\text { Ph.D. in Medicine, Former Director Business Development } \\
\text { in a pharmaceutical company, Consultant in eHealth }\end{array}$ & 24 \\
Expert & $\begin{array}{l}\text { B.Sc. in Business Administration, Former Regional Minister } \\
\text { of Health, Member Advisory Board in eHealth companies }\end{array}$ & 17 \\
Expert & $\begin{array}{l}\text { B.Sc. in Business Administration, Former Director Digital } \\
\text { Solutions in a pharmaceutical company, Analytics Corporate }\end{array}$ & 14 \\
\hline 5 & Director in an health insurance company & \\
\hline
\end{tabular}

propositions relating organizational capabilities to the implementation of eHealth innovation projects.

The second study validates propositions using a multiple case study (Eisenhardt, 1989) comprising seven eHealth innovation projects that have reached an implementation stage (Table 3). Eleven interviewees covered representative stakeholders of eHealth: health managers, health professionals, project developers, and consultants. Sample selec tion follows a strategy similar to the studies on ICT projects in the health sector (Andreassen et al., 2015). The 11 in depth semi structured inter views are face to face or by phone, with durations of $4060 \mathrm{~min}$ in aver age, and the interview provided adapted scripts to each respondent profile. All interviews are on tape and transcript (Table 4).

The unit of analysis in both studies is the interview transcripts, as well as reflections on various documents the respondents provide and other publicly available sources (websites, magazines, and press arti cles) of the last 2 years. Participants in the research are aware of the an onymity of their views and projects' case studies, which enhances respondents' expression of their opinions (Drumwright \& Murphy, 2004).

The analysis triangulates the data (Yin, 1994) of the various data sources. First, the study conducts a thematic analysis (Boyatzis, 1998), coding the data using the capabilities obtained from the literature re view. To refine the results, the research process iteratively feeds back in formation from interviews and from other sources (Eisenhardt, 1989).

\section{Findings}

\subsection{Emerging organizational capabilities}

\subsubsection{Evaluation capability}

Evaluation capability comprises performing an effective evaluation that meets the accepted standards of a discipline (McDonald, Rogers, \& Kefford, 2003). All experts highlight the importance of having an
Table 4

Stakeholders in the second study and their profile.

\begin{tabular}{|c|c|c|}
\hline Stakeholder & Profile & $\begin{array}{l}\text { Number of } \\
\text { interviews }\end{array}$ \\
\hline $\begin{array}{l}\text { Health } \\
\text { managers }\end{array}$ & $\begin{array}{l}\text { General director of information systems, } \\
\text { graduated in computer science } \\
\text { Director of public hospital, graduated in } \\
\text { Medicine }\end{array}$ & 2 \\
\hline $\begin{array}{l}\text { Health } \\
\text { professionals }\end{array}$ & $\begin{array}{l}\text { Medical doctor, specialist in pediatrics } \\
\text { Medical doctor, specialist in dermatology } \\
\text { Medical doctor, specialist in traumatology } \\
\text { Medical doctor, specialist in family and } \\
\text { community health }\end{array}$ & 4 \\
\hline $\begin{array}{l}\text { eHealth } \\
\text { developers }\end{array}$ & $\begin{array}{l}\text { Telecommunications engineer, specializing in IT } \\
\text { applied to the health sector } \\
\text { Informatics engineer }\end{array}$ & 2 \\
\hline $\begin{array}{l}\text { eHealth } \\
\text { consultants }\end{array}$ & $\begin{array}{l}\text { Medical doctor, specialist in surgery } \\
\text { IT health director at consulting firm, graduated in } \\
\text { business administration } \\
\text { Industrial engineer, specialized in eHealth }\end{array}$ & 3 \\
\hline
\end{tabular}

evaluation capability for the implementation of eHealth projects. The evaluation should cover patient needs, include scientific personnel, and take into consideration the organizational context of implementa tion of the innovation project:

In eHealth projects, the first thing to do is to detect the patient's needs (...), to consider which are the patients' pain points. (Expert 5)

The projects require having a scientific and technical evaluation, which usually comes from a health professional. (Expert 4)

One needs to know the organization where the innovation is going to be applied, as well as its operation, so that one can find a favorable context in which to integrate the innovation. (Expert 1)

When evaluating an eHealth project, one needs to accumulate knowledge about the market, especially knowledge about patients, as well as interpreting and acting upon the knowledge obtained (Day, 2011), which implies a deep understanding of the market needs. All these comments lead the study to formulate the following proposition:

Proposition 1. Evaluation capability positively affects the implementa tion of eHealth innovation projects

\subsubsection{Collaborative leadership capability}

Collaborative leadership refers to the integration of ideas and the de velopment of partnerships to find best practices and improvements in business processes (VanVactor, 2012). Experts express in the interviews

Table 3

Description of eHealth projects in the second study.

\begin{tabular}{|c|c|c|}
\hline Project & Description & Type of project \\
\hline $\begin{array}{c}\text { Project } \\
1\end{array}$ & $\begin{array}{l}\text { Web-based information system that displays clinical patient information such as medical history in primary care, specialized reports from } \\
\text { different care services, outstanding appointments, and inter-clinical appointments, among others. }\end{array}$ & $\begin{array}{l}\text { Electronic records } \\
\text { management }\end{array}$ \\
\hline $\begin{array}{c}\text { Project } \\
2\end{array}$ & Public innovation infrastructure aimed at improving the health care of chronically fragile and dependent patients. & Tele-medicine \\
\hline $\begin{array}{c}\text { Project } \\
3\end{array}$ & $\begin{array}{l}\text { Monitoring patients with heart disease by wearable that can record and monitor patients with cardiac pathology in order to improve } \\
\text { diagnosis and therapy of patients. }\end{array}$ & Wearables \\
\hline $\begin{array}{c}\text { Project } \\
4\end{array}$ & $\begin{array}{l}\text { Mobile tool for physicians' consultation and reference. Includes summaries of recent articles published in journals of higher impact factor } \\
\text { and a clinically relevant drug database that includes updated prices and regulation. }\end{array}$ & Mobile health \\
\hline $\begin{array}{c}\text { Project } \\
5\end{array}$ & Platform for diabetes self-management by the patient, and for monitoring, analyzing, and assessing the state of the same by the doctor. & Mobile health \\
\hline $\begin{array}{l}\text { Project } \\
6\end{array}$ & Platform for cognitive rehabilitation of people with brain damage by using learning games defined by therapists. & eHealth \\
\hline $\begin{array}{l}\text { Project } \\
7\end{array}$ & $\begin{array}{l}\text { Platform created to facilitate communication between primary care physicians and hospitals regarding the quality of care, professional } \\
\text { competence and training, and efficiency of the health system. }\end{array}$ & Tele-medicine \\
\hline
\end{tabular}


the need for collaboration in eHealth projects and having a collaborative leadership among stakeholders as key for an implementation:

Health today is an ecosystem with various parties making decisions (...) Everything we do has to be collaborative (...) We have to develop solutions co created by the patient and his eco system. (Expert 5)

One needs to work with the organization, understood as a set of peo ple who produce the service in question, so that they can take own ership of the innovation (...) It is needed a collaborative approach that takes into account all stakeholders. (Expert 1)

Collaborative leadership arises from an organizational culture based on the information that allows taking decisions and communicating them transparently (VanVactor, 2012). The following proposition fol lows the experts' comments.

Proposition 2. Collaborative leadership facilitates the implementation of eHealth innovation projects.

\subsubsection{Stakeholder networking capability}

The post pilot phase requires the creation of networks of stakeholders, who are not equally necessary as those who participate during the eHealth project development phase. Network creation may focus on the diffusion of project results among other stakeholders to attract additional funding or to avoid duplication of work and transmit the accumulated experience, which emerges from the experts' interviews:

It is essential the transmission of the results of the innovation project ... in different areas and networks, whether corporate or social. (Expert 1)

During the dissemination of project results, we cannot ignore the role that some stakeholders can play, who can act as project finan ciers. (Expert 2)

We may need additional funding, and this involves going to talk to potential financiers like the pharmaceutical industry and the labora tories. (Expert 3)

Project managers need to develop the capability of attracting other stakeholders that may provide additional resources for moving the pro jects from pilot to implementation. The following proposition arises from the above comments:

Proposition 3. In eHealth innovation projects, stakeholder networking capability in the post pilot phase helps in the integration of new resources.

\subsubsection{Organizational flexibility capability}

In this research, the concept of organizational flexibility follows Teece, Pisano, and Shuen (1997), considering organizational flexibility as a combination of a repertoire of organizational and managerial capa bilities that allow organizations to adapt quickly under environmental shifts. The interviews show the need of organizational flexibility in sev eral dimensions, such as the operating business model or the diffusion of the knowledge. For instance, Expert 4 highlights the importance of having a flexible business model:

It's important the capacity to develop the business model (...) I ad vised project X, their first approach was "we want to license the soft ware." I said, "do not license the software because it is difficult to protect the intellectual property rights." We set out to follow a SaaS model (...) which involved talking to the device's manufacturer, and included renting rather than selling the device, and the cost was in cluded in the payment for use. (Expert 4)

By contrast, Expert 1 emphasizes the need of flexibility in the inno vation diffusion:

It's important to know how healthcare organizations work, which are the key roles, and from there to evolve to a more flexible position so that they can apply the new knowledge, the new innovation. (Expert 1)

Organizational flexibility capability ensures that the services are what users really need, having a positive influence on the acquisition of new knowledge (Sharma et al., 2014). From the interviews arises the following proposition in relation to organizational flexibility:

Proposition 4. Organizational flexibility capability enables the imple mentation of eHealth innovation projects.

\subsection{Validating the propositions in eHealth innovation projects}

This part analyzes the seven eHealth cases using the four proposi tions. Case material coming from the stakeholders' interviews contrib utes to the propositions' discussion.

\subsubsection{P1 evaluation capability positively affects the implementation of eHealth innovation projects}

The need for scientific and technical evaluation emerges in the sec ond study, particularly the importance of the scientific evaluation:

If there existed a cardiology app, it would be key that the National Society of Cardiology validated that all the contents are appropriate and updated ... We have a group of apps in production, we are fully responsible for them ... and we certified that these apps rely on an alytics that are done in a hospital. (Health Manager 1)

In our case, we have medical advisors ... because in the end, if your application is intended for a medical audience, and it has been ap proved by a doctor, you may reach your target. (eHealth Developer 1 )

[Evaluations] probably are going to be a work of medical associa tions; they have to give a seal of quality to [eHealth] apps. (Health Professional 3)

Implementing a pilot requires performing an evaluation, indicating that the pilot is meeting the needs of the patient, and that the pilot works with existing systems:

Our piloting approach focuses on the patient and integrating the pilot with existing systems ... which leads us to a single, fully inte grated clinical history. (Health Manager 1)

\subsubsection{P2 collaborative leadership facilitates the implementation of} eHealth innovation projects

Collaboration emerges as the keyword in the second study, and sev eral projects consider central to its success the promotion of collabora tion among the different stakeholders involved in the project:

There are some interesting experiences of collaboration networks ... There are communities like $\mathrm{X}$ that have organized committees about tumors using collaborative tools. They can prepare a complex case with its images and documentation, and circulate it among various experts to discuss it. (eHealth Consultant 2)

Collaborative leadership emerges in the projects, in particular, in those involving user communities. 
Our application gives recommendations for X [disease] related to diet, healthy life, etc.... One hundred doctors in Spain are using the system ... we also have an international advisory board with the top ten specialist from Spain and USA. (eHealth Developer 2)

4.2.3. P3 in eHealth innovation projects, stakeholder networking capabil ity in the post pilot phase helps in the integration of new resources

Stakeholder networking capability is key for acquiring knowledge resources:

I have connected with projects in other countries, with professionals from other places to interchange comments and experiences about the project results, ... which has allowed me to get involved in things that otherwise would not be, and incorporate the knowledge in the projects. (Health Professional 4)

Open innovation assumes that firms can use external ideas as well as internal ones, and internal and external paths to market, because the firms aim to improve their technology (Chesbrough, 2006). Stakeholder networks play an important role in open innovation, in particular in knowledge co creation (Kazadi et al., 2016). The interviewees mention the application of open innovation to knowledge co creation in eHealth:

We, in the X project, ... develop what the community says ... it's an open innovation process in which the community itself gives ideas and tells you what you need and how you need it ... you try it for free before it sets the market ... and part of the success of our project is that. (eHealth Developer 2)

Furthermore, the importance of stakeholder networking and diffu sion for obtaining additional investment for pilots is evident:

There is a need for more coordination networks and adequate dis semination of results: with the limited resources we have, it is not possible having uncoordinated eHealth projects between the differ ent [autonomous] regions. (Health Manager 2)

The results indicate the importance of stakeholder networking to in tegrate resources, but the main resource to integrate them is knowledge.

4.2.4. P4 organizational flexibility capability enables the implementation of eHealth innovation projects

The medical context considers eHealth as a changing field, which evolves constantly and requires that people, processes, and products evolve too.

In a few years, we will monitor electrocardiograms and connect them to iPhone with very little money (...) if you can send this infor mation to the cardiologist of a patient with bad heart, you will change his quality of life ... in coming years the number of devices that go online will increase (...). The technology must be adapted to each person (...). One has to adapt to the technological changes and to the [digital] literacy of the patients. (Health Professional 1)

Patients' needs contribute to updating eHealth projects:

[Specialists like me] digitize what we do every day (...). I'm turning information into a much more active patient monitoring system. I am developing logic trees that, as the patient is giving me information, I'll be giving them personalized answers. (Health Professional 4)

\section{Conclusions}

The research explores how organizational capabilities contribute in transitioning eHealth innovation projects from pilots to real implementations. Four propositions relating organizational capabilities to the implementation of eHealth projects arise from the analysis. First, evaluation capability positively affects the implementation of eHealth innovation projects. The analysis shows that the evaluation ca pability should be as wide as possible, covering the patients' needs, a sci entific/medical point of view, and the organizational context.

The second proposition states that collaborative leadership facilitates the implementation of eHealth projects. Experts see health today as an ecosystem with various parties taking decisions. In the center of such eco system is the patient because the patients and other members of the eco systems co create many of the initiatives related to the eHealth project. The leader member exchange theory serves as basis for collaborative leadership, which posits that leadership occurs when leaders and fol lowers are able to develop effective relationships and partnerships that result in influences (Uhl Bien, 2006). The study finds evidence of such ef fective relationships and partnerships in the eHealth projects, and the projects consider such type of strategic leadership in their success.

The third proposition relates stakeholder networking capability with the integration of new resources. Although the study finds evi dence supporting this proposition, the results include some differences between the experts' view and the eHealth projects analyzed in relation to the type of new integrated resources. In the first study, experts em phasize stakeholder networking capability as key for attracting the nec essary financial resources for the implementation of the project. Most eHealth projects use stakeholder networking capability for attracting new knowledge and consider this capability important for the success and sustainability of their projects. Dyer and Singh (1998) argued that relationships with partners outside the firm can enable company access to different additional resources, such as financial, intellectual, and human capital, supporting the opinions of both the experts and the eHealth projects.

The fourth proposition relates organizational flexibility capability with the implementation of eHealth projects. The study finds evidence supporting this relation. In particular, flexibility for updating the business model operation emerges as important for the projects. This result is in line with previous studies that recommend eHealth projects to include a business model description and a business case as part of their implementation strategy (van Limburg et al., 2011).

The main contribution of this work is the identification of the main capabilities required for taking eHealth innovation projects from pilots to real implementations. Of the four capabilities identified, evaluation capability rises as an essential one, with many respondents mentioning the lack of proper evaluation as the reason for failure in several eHealth initiatives.

A customer centric approach emerges from the research. Both the experts and the eHealth projects manifest that customers in this case, patients have taken a central role. This customer centricity is also evi dent in some of the identified capabilities: evaluation capability for eHealth projects should start "evaluating patients' needs," and patients should be the center of the ecosystem for collaborative leadership. Trust determines the establishment and maintenance of relationships between customers and service providers, playing a fundamental role in online environments (Urueña \& Hidalgo, 2015) like eHealth projects.

Finally, the research has some limitations. As this study focuses ex clusively in one country and one sector, future studies should examine the proposed capabilities from a broader context, including several countries and other sectors. Such research could lead to a more nuanced understanding of organizational capabilities in innovation projects.

\section{References}

Andreassen, H. K., Kjekshus, L. E., \& Tjora, A. (2015). Survival of the project: A case study of ICT innovation in health care. Social Science \& Medicine, 132, 62-69.

Barney, J. (1991). Firm resources and sustained competitive advantage. Journal of Management, 17(1), 99-120.

Borkan, J., Eaton, C. B., Novillo-Ortiz, D., Corte, P. R., \& Jadad, A. R. (2010). Renewing primary care: Lessons learned from the Spanish health care system. Health Affairs, 29(8), $1432-1441$ 
Boyatzis, R. E. (1998). Transforming qualitative information: Thematic analysis and code development. Thousand Oaks, CA: Sage.

Broens, T. H., Vollenbroek-Hutten, M. M., Hermens, H. J., van Halteren, A. T., \& Nieuwenhuis, L. J. (2007). Determinants of successful telemedicine implementations: A literature study. Journal of Telemedicine and Telecare, 13(6), 303-309.

Calantone, R. J., Cavusgil, S. T., \& Zhao, Y. (2002). Learning orientation, firm innovation capability, and firm performance. Industrial Marketing Management, 31(6), 515-524.

Car, J., Black, A., Anandan, C., Cresswell, K., \& Pagliari, C. (2008). The impact of eHealth on the quality \& safety of healthcare a systematic overview \& synthesis of the literature. Report for the NHS Connecting for Health Evaluation Programme.

Chesbrough, H. W. (2006). Open innovation: The new imperative for creating and profiting from technology. Boston, MA: Harvard Business Press.

Christensen, C. (1997). The innovator's dilemma. Boston, MA: Harvard Business School Press.

Codagnone, C., \& Lupiañez-Villanueva, F. (2013). Benchmarking deployment of ehealth among general practitioners. Final report. Publications Office of the European Union. Luxembourg: European Commission.

Day, G. S. (1994). The capabilities of market-driven organizations. Journal of Marketing, $58(4), 37-52$.

Day, G. S. (2011). Closing the marketing capabilities gap. Journal of Marketing, 75(4), 183-195.

de Bont, A., \& Bal, R. (2008). Telemedicine in interdisciplinary work practices: On an IT system that met the criteria for success set out by its sponsors, yet failed to become part of every-day clinical routines. BMC Medical Informatics and Decision Making, $8(1), 47$.

Den Hertog, P., Van der Aa, W., \& de Jong, M. W. (2010). Capabilities for managing service innovation: Towards a conceptual framework. Journal of Service Management, 21(4), 490-514.

Drumwright, M. E., \& Murphy, P. E. (2004). How advertising practitioners view ethics: Moral muteness, moral myopia, and moral imagination. Journal of Advertising, 33(2), 7-24.

Dyer, J. H., \& Singh, H. (1998). The relational view: Cooperative strategy and sources of interorganizational competitive advantage. Academy of Management Review, 23(4), 660-679.

Eisenhardt, K. M. (1989). Building theories from case study research. Academy of Management Review, 14(4), 532-550.

Eysenbach, G. (2001). What is e-health? Journal of Medical Internet Research, 3(2), e19.

Forés, B., \& Camisón, C. (2016). Does incremental and radical innovation performance depend on different types of knowledge accumulation capabilities and organizational size? Journal of Business Research, 69(2), 831-848.

Francis, D., \& Bessant, J. (2005). Targeting innovation and implications for capability development. Technovation, 25(3), 171-183.

Galvagno, M., \& Dalli, D. (2014). Theory of value co-creation: A systematic literature review. Managing Service Quality, 24(6), 643-683.

Gomm, R., Hammersley, M., \& Foster, P. (2000). Case study method: Key issues, key texts. London: Sage.

Grant, R. M. (1996). Toward a knowledge based theory of the firm. Strategic Management Journal, 17(S2), 109-122.

Gregor, S. (2006). The nature of theory in information systems. MIS Quarterly, 30(3), 611-642.

Hedberg, A., \& Morosi, M. (2015). Keeping health high on the EU agenda: Role for economic governance? EPC Policy Brief (7 May 2015).

Kazadi, K., Lievens, A., \& Mahr, D. (2016). Stakeholder co-creation during the innovation process: Identifying capabilities for knowledge creation among multiple stakeholders. Journal of Business Research, 69(2), 525-540.
Le Masson, P., Weil, B., \& Hatchuel, A. (2010). Strategic management of innovation and design. New York: Cambridge University Press.

Lewin, K. (1945). The research center for group dynamics at Massachusetts Institute of Technology. Sociometry, 8(2), 126-136.

Lupiañez, F., Maghiros, I., \& Abadie, F. (2013). Citizens and ICT for health in 14 European countries: Results from an online panel. Strategic intelligence monitor on persona health systems, Phase 2. JRC scientific and policy reports (European Commission). Sevilla: Joint Research Center.

Madhavan, R., \& Grover, R. (1998). From embedded knowledge to embodied knowledge: New product development as knowledge management. The Journal of Marketing, 62(4), 1-12.

Mair, F. S., May, C., O'Donnell, C., Finch, T., Sullivan, F., \& Murray, E. (2012). Factors that promote or inhibit the implementation of e-health systems: An explanatory systematic review. Bulletin of the World Health Organization, 90(5), 357-364.

Makadok, R. (2001). Toward a synthesis of the resource-based and dynamic-capability views of rent. Strategic Management Journal, 22(5), 387-401.

Martelo, S., Barroso, C., \& Cepeda, G. (2013). The use of organizational capabilities to increase customer value. Journal of Business Research, 66(10), 2042-2050.

McDonald, B., Rogers, P., \& Kefford, B. (2003). Teaching people to fish? Building the evaluation capability of public sector organizations. Evaluation, 9(1), 9-29.

Miles, M. B., Huberman, A. M., \& Saldana, J. (2013). Qualitative data analysis: A methods sourcebook. Thousand Oaks, CA: Sage.

O'Connor, G. C. (2008). Major innovation as a dynamic capability: A systems approach. Journal of Product Innovation Management, 25(4), 313-330.

Patton, M. Q. (2002). Qualitative evaluation and research methods (3rd ed.). Thousand Oaks, CA: Sage.

Romijn, H., \& Albaladejo, M. (2002). Determinants of innovation capability in small electronics and software firms in southeast England. Research Policy, 31(7), 1053-1067.

Sharma, S., Conduit, J., \& Hill, S. R. (2014). Organizational capabilities for customer partic ipation in health care service innovation. Australasian Marketing Journal, 22(3), 179-188.

Teece, D. J. (2014). A dynamic capabilities-based entrepreneurial theory of the multinational enterprise. Journal of International Business Studies, 45(1), 8-37.

Teece, D. J., Pisano, G., \& Shuen, A. (1997). Dynamic capabilities and strategic management. Strategic Management Journal, 18(7), 509-533.

Uhl-Bien, M. (2006). Relational leadership theory: Exploring the social processes of leadership and organizing. The Leadership Quarterly, 17(6), 654-676.

Urueña, A., \& Hidalgo, A. (2015). Successful loyalty in e-complaints: FsQCA and structural equation modeling analyses. Journal of Business Research, 69(4), 1384-1389.

Van de Ven, A. H., \& Poole, M. S. (2005). Alternative approaches for studying organizational change. Organization Studies, 26(9), 1377-1404.

van Limburg, M., van Gemert-Pijnen, J. E., Nijland, N., Ossebaard, H. C., Hendrix, R. M., \& Seydel, E. R. (2011). Why business modeling is crucial in the development of eHealth technologies. Journal of Medical Internet Research, 13(4), e124.

VanVactor, J. D. (2012). Collaborative leadership model in the management of health care Journal of Business Research, 65(4), 555-561.

Woodside, A. G., \& Wilson, E. J. (2003). Case study research methods for theory building. Journal of Business \& Industrial Marketing, 18(6/7), 493-508.

Wu, H., Chen, J., \& Jiao, H. (2016). Dynamic capabilities as a mediator linking international diversification and innovation performance of firms in an emerging economy. Journal of Business Research, 69(8), 2678-2686.

Wyatt, J. C., \& Sullivan, F. (2005). eHealth and the future: Promise or peril? BMJ: British Medical Journal, 331(7529), 1391-1393.

Yin, R. (1994). Case study research: Design and methods. Thousand Oaks, California: Sage. 